Beyond Philology No. 15/1, 2018

ISSN 1732-1220, eISSN 2451-1498

\title{
Me nem nesa: \\ Investigating the reception \\ of constructed languages \\ in different age groups
}

\author{
MAJA GAJEK
}

Received 25.11.2017,

received in revised form 28.06.2018,

accepted 29.06.2018.

\begin{abstract}
The concept of artificially created languages is not new, but, owing to pop culture, it has recently received more attention. Constructed languages, or conlangs, are present in books, movies and video games, aimed at recipients of all ages. Contrary to natural languages, which emerged without conscious planning, constructed languages are designed to serve a certain purpose.

There are many motives triggering the creation of new languages, from linguistic experiments and language games to making communication easier. However, the most common reason behind the emergence of artificial languages during the last twenty years appears to be the enrichment of the world they belong to. Interestingly, the response of the audience varies depending on age. The aim of this paper is to examine samples of constructed languages present in recent pop culture and the effects they have on both their respective target groups and the rest of the audience.
\end{abstract}

\section{Keywords}

constructed language, conlang, Minionese, Atlantean, Na'vi, Dothraki 


\title{
Me nem nesa: \\ Badanie recepcji języków sztucznych przez różne grupy wiekowe
}

\begin{abstract}
Abstrakt
Zjawisko sztucznie tworzonych języków nie jest nowe, ale dzięki popkulturze cieszy się ostatnio większą uwaga. Języki sztuczne, znane pod nazwą conlang, sa obecne w książkach, filmach oraz grach wideo skierowanych zarówno do młodych, jak i dojrzałych odbiorców. W przeciwieństwie do języków naturalnych, które powstały bez świadomego planowania, języki sztuczne zostały zaprojektowane przez autorów aby spełnić określony cel.

Istnieje wiele motywów powodujących powstawanie nowych języków, od eksperymentów i gier językowych po ułatwianie komunikacji. Jednak najczęstszym powodem tworzenia sztucznych języków w ciągu ostatnich dwudziestu lat wydaje się być wzbogacenie świata, w którym występują. Interesujące jest to, że reakcja publiczności różni się zależności od wieku. Celem niniejszego tekstu jest zbadanie przykładów języków sztucznych obecnych w najnowszej popkulturze i reakcji zarówno docelowej grupy widzów, jak i pozostałych odbiorców.
\end{abstract}

\section{Słowa kluczowe}

język sztuczny, conlang, Minion, Atlantean, Na'vi, Dothraki

\section{Introduction}

According to the 20th edition of Ethnologue, released on February $21^{\text {st }} 2017$, there are currently 7,099 living languages (Simons 2017), all of which have a common ancestry. They were not "invented", they evolved, mutually influencing each other. As Okrent (2009: 5) states,

Someone said something a certain way, someone else picked up on it, and someone else embellished. A tendency turned into a habit, and somewhere along the way a system came to be. [...] 
This is the way all natural languages are born - organically, spontaneously.

Natural development is what makes these languages fundamentally different from the so-called constructed languages. Calling certain groups of languages "families" is no accident since at some point in the history they had a common ancestor, cf. the Indo-European languages. A similar set of relationships cannot be drawn between constructed languages.

A constructed language can be defined in many ways. Based on the available literature, the most basic definition that applies to the majority of conlangs is the following:

A language which has not developed naturally and whose grammar, vocabulary and phonology have been consciously devised by the creator.

Looking at the development process, two types of such languages can be distinguished: a priori and a posteriori conlangs. The a priori type refers to languages whose features are not based on an existing language. A posteriori languages are the opposite, they borrow from or are built upon another language. And yet, assigning any given constructed language to one of those two types typically causes many difficulties as the majority fall between a priori and a posteriori.

Even naming artificially made languages causes problems. The majority of studies use the name constructed languages for the system and conlangers for the authors, however terms like "fictional", "planned" or "invented" are also used, most likely to avoid repetitions, although on some occasions using a synonym changes the intended meaning.

The phenomenon is not a new one; the so-called "debate over language creation" dates back to ancient Greece (Boozer 2013: 1). According to Okrent (2009: 10), the first welldocumented constructed language is called Lingua Ignota (Lat. 'unknown language') and is attributed to Hildegard von Bing- 
en. The nun claimed that the language was revealed to her by God in one of her visions. Vocabulary sample of Lingua Ignota:

(1) Aieganz 'angel'

Díuueliz 'devil'

Vanix 'woman'

Jur 'man'

(Boozer 2013: 2)

Over the centuries, numerous constructed languages followed. The purpose of their creation varied, depending on the era, but typically the main goal was to improve a natural language in order to ease communication. As Adams (2011: 3) claims,

The origin and development of each invented language illustrates its inventor's sense of language, what it is, and what it should do, in linguistic and historical terms; each also implies its inventors' and users' dissatisfactions with the language(s) already available to them.

Without any doubt, the most popular constructed language is Esperanto. Its creator, Ludwik Zamenhof, was not interested in redesigning an existing language. He longed for a peaceful world and believed that a common language, which would eliminate the sense of belonging to a certain country, was a significant step towards peace. Zamenhof's legacy is remarkable; a hundred years after his death, Esperanto is recognized as practically equal with natural languages and has around two million native speakers (Boozer 2013: 3). So far it is the only constructed language in history to achieve that.

Another possible reason behind language creation is a linguistic experiment to prove or test a theory, as in the case of Toki Pona and Loglan, or simply an exercise for students. However, such languages usually receive little recognition.

During the last few years a certain trend in pop-culture can be observed. Constructed languages have received renewed interest thanks to fantasy media. They emerge to enrich the worlds they belong to. Such creations are called "artistic con- 
langs" and belong to the most rapidly growing sub-group. The most prominent examples are Klingon, Quenya and Sindarin. Those conlangs have much in common: they were all designed for a fantasy/sci-fi universe, are deeply imbedded in culture, and were coined by professional linguists who put much effort in developing them. In a letter from 1916, J. R. R. Tolkien mentions:

I have done some touches to my nonsense fairy language - to its improvement. I often long to work at it and don't let myself 'cause though I love it so it does seem such a mad hobby!

(Carpenter and Tolkien 2006)

That statement shows that for this author conlanging was a form of entertainment, a challenging hobby. Stockwell (2006: 8) notes that some conlangs "are worked out far beyond the requirements of the fictional world they occupy" and Tolkien's numerous invented languages are excellent examples; they are perfectly suitable for their respective native speakers and, in the case of Quenya and Sindarin, even have an internal history of development.

Despite the unparalleled position which Klingon and the Elvish languages have among the artistic conlangs, younger generations tend to treat them as relics of the past. Conlangs have entered a modern era owing to the Internet, where a thriving community from all around the world can talk about this peculiar hobby. Moreover, in 2007 the Language Creation Society was established to promote the art of language creation. The members publish their findings in journals and present their papers at dedicated conferences.

\section{The experiment}

During my own presentations on Tolkien's conlangs I noticed different reactions from the audience: everybody knew that languages such as Quenya and Sindarin exist, but Khuzdul always confused the interlocutors. This encouraged me to con- 
duct an experiment examining the reception of less-known constructed languages.

The first stage of the experiment took place in December 2016 and April 2017. Originally the participants were divided into two groups: "children" and "adults". When, during the summer of 2017 the number of examined people grew, a new age group was recognized:

- Group 1: "children" - 5 subjects aged 5-15;

- Group 2: "young adults" - 6 subjects aged 19-30;

- Group 3: "adults" - 8 subjects aged 35-50.

None of the subjects had any interest in the field of constructed languages or linguistics. Three of them were native speakers of English, the others were Polish, but this factor proved to be insignificant.

The subjects were informed that they had taken part in an experiment only after giving their responses. The follow-up questions blended smoothly into a normal conversation. The subjects were asked to watch three movies and four episodes of a TV series, each of which featured an artificial language. During the research I focused on answering the following questions:

- Did the subject notice the presence of an artificial language?

- What was the reaction of the viewers to the presence of an artificial language?

- Did the language influence the fandom and/or merchandise surrounding the movie in any way?

- Was the language needed in the movie/TV series?

The examples of languages were chosen from those of low popularity. Thus, the study disregarded languages such as Klingon or the Elvish languages, which are treated as prototypical examples. Instead, conlangs such as Minionese, Atlantean, Na'vi and Dothraki were selected. 


\section{Minionese}

The first of these is officially called the Minion language, or Minionese, but it was also dubbed "Banana language". It appears in the Despicable Me movie franchise and is spoken by little yellow creatures called Minions.

The creation of the Minion language appears quite simple and accidental. The majority of the vocabulary came from the directors, Pierre Coffin and Chris Renaud. Neither of them has any linguistic background, and they did not seek any professional assistance. In Despicable Me 2 production notes (2013: 15), Coffin remarks:

So, these words pop out, and I have them speak Indian, French, English, Spanish and Italian. I mix up all these ridiculous sounding words just because they sound good, not because they necessarily mean something.

Renaud continues (2013: 15):

Their language sounds silly, but when you believe that they're actually communicating that's what makes it funnier. What's great about the Minion language, while it is gibberish, it sounds real because Pierre puts in words from many languages and does the lion's share of the Minion recordings.

Because of the randomness of the creation process, recognizing any grammatical rules of Minionese is impossible. Hence, all available dictionaries and translations are made by fans rather than linguists, and based only on the material from the movies and fan-theories. Examples:

(2) Bakayarou 'stupid' (Jap. bakayarou, 'stupid', used as an insult)

Tulaliloo ti amo 'we love you' (It. ti amo, 'I love you')

Babble 'apple'

Bee do bee do 'fire' 
According to the Motion Picture Association of America (MPAA), the series was rated PG - parental guidance suggested, which indicates the target audience is children aged 6+. Despite that, the movies are also popular among older audiences.

Not all of the participants in my study had seen any Minionrelated movie before watching one as a part of the research, although, surprisingly, everyone was familiar with the Minions, presumably due to global merchandise. The movie selected was the 2015 Minions as it features the most examples of the language.

Characteristically, the youngest subjects in group 1 were most enthusiastic about hearing the Minion language. Their focus, however, was on sounds and the volume of the dialogue rather than its content. Repetitions and attempts at creating new words in Minionese were also very common and mostly took the form of onomatopoeic expressions.

The responses of members of group 2 ("young adults") were quite similar to those of the "children". The difference was that the participants recognized the vocabulary as coming from Japanese, Italian, etc., and they did not pay so much attention to the way the dialogues were delivered. Out of six participants, four took considerable interest in the language and later searched for more information about Minionese.

The "adults" found the whole concept of the Minions ridiculous. Obviously, they were never the target audience of the movie, however, as shown by the "young adults" group, even the older public can enjoy it. Some of the words were recognized as coming from natural languages, but only one of the participants wanted to know more about Minionese.

There is no denying that the Minions draw attention not only because of the way they look, but also because of the way they talk. The aim of this barely intelligible, nonsensical language is to add a comical element, and enrich both their personality and the movie. 


\section{Atlantean}

The second language selected for the study has a more "professional" background. This time placing a constructed language in a movie production carried a deeper meaning. The Atlantean language was created for the 2001 Disney animation Atlantis: The Lost Empire, for the native inhabitants of Atlantis. The movie follows the adventures of Milo Thatch, who dreams of finding Atlantis with the help of the mysterious Shepherd's Journal. The producer, Don Hahn, had a fixed idea about the native inhabitants of Atlantis and hired a professional linguist, Marc Okrand, to help him achieve his goal:

What the directors and I wanted to do with the movie was create an Atlantis that was a mother civilization both in terms of its language and its architecture. We wanted to create a civilization that really felt like it was the wellspring of all other civilizations and that's how it's described in a lot of mythology. [...] Marc Okrand who did the Klingon language for Star Trek came in and helped us develop a spoken dialect for the Atlanteans that was the same thing, kind of a primitive dialect that you could imagine was like the dialects people spoke before the Tower of Babel - a 'root' dialect. (Henning 2008)

Dr. Marc Okrand is famous for creating two constructed languages for the Star Trek universe, Klingon and the less-known Vulcan. He started working on Atlantean around 1996. His attention to detail resulted not only in a set of vocabulary and expressions needed for the dialogues, but also provided a complex phonology, grammar and writing script. The symbols were supposed to be similar to alphabets like Phoenician and Sanskrit. Here is a sample sentence in Atlantean:

(3) Nishentop Adlantisag, kelobtem Gabrin karoklimik bet gim demottem net getunosentem bernotlimik bet kagib lewidyoh.

'Spirits of Atlantis, forgive me for defiling your chamber and bringing intruders into the land.' 
The alphabet plays a significant role in the movie. The Atlanteans were illiterate and upon his arrival, Milo was the only one who could read the ancient script and help the Atlanteans restore their kingdom to its former glory. He had to reconstruct the long-forgotten language in order to read the Journal.

It should be noted that in the majority of children's movies, the issue of foreign languages is usually disregarded; the characters simply speak the same language or are able to understand each other. In Atlantis (Trousdale and Wise 2001), however, the problem is logically explained:

(4) Audrey: How do they know all these languages?

Milo: Their language must be based on a root dialect. It's just like the Tower of Babel.

The scene of the first meeting between Milo's expedition and the Atlanteans is fascinating also because of how fluently Milo and princess Kida move from speaking Atlantean to English. It shows how closely the Romance languages are connected: the interlocutors move through Latin, Italian and arrive at French. Then, the explorers come to the conclusion that the natives might know English as well. As a result, Atlantean is both fictional and based on historical reconstructions, which gives it even more credibility.

Atlantis: The Lost Empire was rated PG, although the target audience remains unclear. Since the movie was not a great success for Disney, it is no wonder that none of the subjects in my study was familiar with this animation.

There are quite a few dialogues in the movie conducted entirely in Atlantean and subtitled in English. Therefore, even the youngest study group noticed the presence of a foreign language. But aside from being aware of it, the subjects in all three groups ignored Atlantean and not one of them asked about it later. Only the children mentioned that they liked the "weird-looking" alphabet.

Based on these responses, it seems that a certain amount of knowledge about historical linguistics is required to fully ap- 
preciate the constructed language in this case. The lack of any interest amongst all age groups shows that, for an average viewer, giving the Atlanteans their vernacular was unnecessary.

\section{Na'vi}

The third language chosen for the study was that of the humanoid aliens from James Cameron's award-winning movie Avatar. Na'vi was created by a professional linguist, Paul Frommer, who claims that the director had a specific vision about what the language should look and sound like:

He wanted a complete language, with a totally consistent sound system, morphology, syntax, he wanted it to sound good - he wanted it to be pleasant, he wanted it to be appealing to the audience (Montagne 2009).

Dr. Frommer was first approached in 2005 and given around 30-40 sample words to work with. It helped him to see what the director had in mind when it came to phonology (Milani 2009). Upon Avatar's release in 2009, the language had around a thousand words. Now, eight years later, the most popular website about Na'vi (learnnavi.org) claims that this number has doubled. 1

The target audience for Avatar is the more mature public as it was rated PG-13 (parents strongly cautioned). What makes the younger viewers interested is mostly the animation and the created world of Pandora, full of colours and extraordinary creatures. All of my participants had seen the movie multiple times before, but no one objected to watching it again; it is still the symbol of a new era in science-fiction productions because of the outstanding visual effects.

Like in the case of Atlantean, the "children" noticed the harsh-sounding foreign language right away, but this time they asked the parents if the creatures were speaking an "In-

\footnotetext{
$1<$ learnnavi.org>, July 2017.
} 
dian language". Based on the Na'vi's look, behaviour and the sounds of their language, it is possible that for the youngest audience the members of the alien tribe seemed similar to Native Americans.

Study groups 2 and 3 unanimously found the language interesting only as an element of culture. The "young adults" briefly wondered about the origins of $\mathrm{Na}$ 'vi, however, their interest did not exceed that. It is true that the movie offers very few samples of the vernacular as even the dialogues between the Na'vi are conducted almost entirely in English. This might be the reason why for an average viewer there was not enough language input to draw more attention. The plot shows that the Na'vi were taught English at some point and were relatively fluent in it, therefore creating an entirely new language for them was not obligatory. Once again, a conlang was an important element of giving the people an identity, but not the only element. Examples:

(5) Kaltxi 'hello' (casual)

Oel ngati kameie I see you' (hello, familiar greeting) Irayo 'thanks'

The creation of the Na'vi language was a kind of revival of constructed languages as it was the first relatively popular conlang to appear in many decades. Multiple tutorials and language courses were available soon after the release of Avatar. People from around the world were learning Na'vi and conversing in it. In an interview from 2009, Frommer shared his hopes about Na'vi achieving a status similar to Klingon (Montagne 2009). He maintains a blog where he regularly posts about linguistic changes and novelties. This conlang's popularity has been steadily decreasing over the last few years; however, with at least two new movies set in the Avatar universe to be released in the future, this scenario is once again becoming a possibility. 


\section{Dothraki}

The last language, Dothraki, is the one which has gained the most popularity in recent years. Created by a linguist, David J. Peterson, one of the founding fathers of Language Creation Society, it appears in George R.R. Martin's A Song of Ice and Fire saga and HBO's Game of Thrones TV series. "In designing Dothraki, I wanted to remain as faithful as possible to the extant material in George R.R. Martin's series," Peterson claims, and names Russian, Turkish, Estonian, Inuktitut and Swahili as his inspiration (Official HBO release 2010).

As the language of a nomadic tribe of horsemen, Dothraki lacks any writing system and features rather guttural and harsh sounds. It is not the only conlang Peterson was asked to create for Game of Thrones. During the last few seasons, we have had the opportunity to hear the more elegant-sounding Valyrian as well.

Game of Thrones is obviously aimed at a mature audience; thus, in the case of the youngest study group, we watched only the scenes where the dragons appear. Unfortunately, the lengthy Dothraki dialogues are only subtitled, which made them quite irritating for the youngest subjects who found the need to read annoying and paid no attention to the language itself.

Among the older audience from groups 2 and 3, the majority are Game of Thrones fans. Four subjects from "young adults" and four "adults" did some research about the language's background. All thought that it is "appropriate" for the Dothraki people, and somewhat savage. Examples:

(6) Me nem nesa 'it is known'

Yer Jalan Atthirari Anni 'moon of my life'

Shekh Ma Shieraki Anni 'my sun and stars'

Recently Valyrian has taken Dothraki's place when it comes to frequency of use, but despite that, the popularity of the latter is still enormous. Expressions such as me nem nesa are com- 
monly used not only by die-hard fans, but also by people who simply enjoy the series. An official Dothraki course was released in 2014, and it is possible that one for Valyrian will follow. Peterson has become quite an expert when it comes to language creation for modern-day media. Aside from his Game of Thrones projects, he has also created conlangs for Marvel's Thor: The Dark World, Doctor Strange, The Shannara Chronicles and many others. It is due to his attention to details that his creations fit their native speakers and seem as real as natural languages for the audience.

\section{Conclusions}

The results of the study are collected in Table 1, which presents the audience response to the four discussed languages.

As the data shows, in all cases the presence of a constructed language in the movie or TV series was noticed by every age group. The differences are found in the audience reactions. Some of them were expected (e.g. the positive reaction of the youngest participants in the case of Minionese), the others were quite a surprise (e.g. the equally enthusiastic response of the young adults). It was interesting to see that the responses differed even between groups 2 and 3, where the participants were all adults and their reactions could have been identical. The most concerning is the lack of response to the Atlantean language; it appears that the characteristics chosen by the author did not appeal to the audience. On the other hand, it is possible that the decisive factor was the movie's mediocre popularity and rather unsuccessful marketing campaign. The ability to understand a conlang either via subtitles or following explanations also seems to be essential to fully appreciate what it brings to the production. In the majority of the cases, creating an artificial language was by no means obligatory, but its presence made a significant contribution to the way the movie or TV series was received. 
Table 1

Results of the experiment

\begin{tabular}{|l|l|l|l|l|l|}
\hline \multicolumn{2}{|c|}{ Question } & Minionese & Atlantean & \multicolumn{1}{|c|}{ Na'vi } & \multicolumn{1}{|c|}{ Dothraki } \\
\hline Noticed? & all: yes & all: yes & all: yes & all: yes \\
\hline \multirow{3}{*}{ Reaction? } & children & positive & indifferent & $\begin{array}{l}\text { indifferent/ } \\
\text { positive }\end{array}$ & negative \\
\cline { 2 - 6 } & $\begin{array}{l}\text { young } \\
\text { adults }\end{array}$ & positive & indifferent & positive & positive \\
\cline { 2 - 6 } & adults & indifferent & indifferent & positive & positive \\
\hline Influence? & $\begin{array}{l}\text { extremely } \\
\text { significant }\end{array}$ & scarce & $\begin{array}{l}\text { very } \\
\text { significant }\end{array}$ & significant \\
\hline Needed? & yes & no & no & yes/no \\
\hline
\end{tabular}

Looking at the artistic conlangs, it is practically impossible to find one which is disliked by the majority of the public. Conlangs have become an essential element of every fantasy or science-fiction universe, and with the growing number of new publications such as books, movies, TV series and video games we can expect more conlangs to appear.

At present, constructed languages are on the rise. The main purpose behind their inventions is no longer the ease of communication or trying to find the language of the Tower of Babel. As Stockwell (2006: 6) remarks, "[i]nventing new languages is not simply the preserve of literary fiction". We observe an extraordinary triumph of the artistic conlangs and this phenomenon deserves attention as there is still much research to be done. The issues such as what makes a constructed language appealing, the importance of the level of familiarity or the pattern for creating a successful constructed language will hopefully be explored by enthusiastic conlangers in the near future. 


\section{References}

Adams, Michael (2011). From Elvish to Klingon: Exploring Invented Languages. Oxford: Oxford University Press.

Anderson, Stephen R. (2010). How many languages are there in the world? Available at <https://www.linguisticsociety.org/content/ how-many-languages-are-there-world >. Accessed 13.09.2017.

Atlantean (Dig Adlantisag) (n.d.). Available at <http://www.omniglot. com/conscripts/atlantean.htm>. Accessed 10.06.2017.

Boozer, Don (2013). "Conlanging: An introduction to the art of language creation". In: FL-000015-00, Fiat Lingua. Available at <http://fiatlingua.org>. Accessed 12.01.2017.

Carpenter, Humphrey, Christopher Tolkien (2006). The Letters of J. R. R. Tolkien. HarperCollins. Kindle file.

Despicable Me 2. Production Notes (2013). Available at <www.visual hollywood.com/movies_2013/despicable_me_2/notes.pdf $>$. Accessed 15.10.2017.

Henning, Jeffrey (2008). Atlantean Metahistory. Available at <http:// web.archive.org/web/20080707004131/http://www.langmaker. com/atlanteanmetahistory.htm>. Accessed 10.06.2017.

Milani, Matteo (2009). An interview with Paul Frommer, Alien Language Creator for Avatar. Available at <http://usoproject.blog spot.com/2009/11/interview-with-paul-frommer-alien.html>. Accessed 10.06.2017.

Montagne, Renee (2009). Do You Speak Na'vi? Giving Voice To 'Avatar' Aliens. Available at <http://www.npr.org/templates/story/story. php?storyld=121350582>. Accessed 10.06.2017.

Official HBO Press Release (2010). Available at <http://dothraki. conlang.org/official-hbo-press-release/>. Accessed 20.09.2017.

Okrent, Arika (2009). In the Land of Invented Languages: Adventures in Linguistic Creativity, Madness, and Genius. New York: Random House Publishing Group.

Simons, Gary F., Charles D. Fennig (eds.) (2017). Ethnologue: Languages of the World, Twentieth edition. Dallas, Texas: SIL International. Available at <http://www.ethnologue.com>. Accessed 20.09.2017.

Stockwell, Peter (2006). Invented Language in Literature. In: Keith Brown (ed.). Encyclopedia of Language \& Linguistics. Second Edition. Volume 6. Oxford: Elsevier, 3-10.

Trousdale, Gary, Kirk Wise (dir.) (2001). Atlantis: The Lost Empire. USA: Walt Disney Pictures. 


\section{Maja Gajek}

ORCID iD: 0000-0003-4758-240X

Uniwersytet Warszawski

Instytut Anglistyki

ul. Hoża 69

00-681 Warszawa

Poland

mgajek@student.uw.edu.pl 